\title{
Easy access: new dynamics in long-distance African intimacies
}

\author{
Dinah Hannaford
}

Recent scholarship in migration studies has highlighted the pervasiveness of longdistance intimate relationships in contemporary migration. These relationships include transnational practices of parenting (see, for example, Parreñas 2005; Feldman-Savelsberg 2016), supporting siblings and parents from abroad, and long-distance marriages, the focus of my own research. These relationships, I have argued, represent a particular twenty-first-century imperative for flexibility and mobility in the neoliberal era, particularly for those in the global South. Contemporary economic and political forces of neoliberal globalization are deeply intertwined with the cultural construction and configurations of intimate relationships (see also Trémon 2017).

Of course, for denizens of Africa, mobility itself is not a new phenomenon. Migration is an essential part of African history and culture. Precolonial African movement was associated with warfare, natural disasters, and the search for arable land for agriculture (Adepoju 1979). Colonialism set in motion new types of urbanization and labour migration across the continent as natural resources were extracted for exportation. Postcolonial Africa, particularly since the 1980s, has seen increasing practices of economic migration out of the continent, particularly towards the global North, although the majority of African migration remains intra-continental (Flahaux and De Haas 2016; Whitehouse 2012; Kane and Leedy 2013; Declich and Rodet 2018).

Long-distance intimacies are likewise not necessarily a new feature of African migration stories. African history provides many examples of earlier attempts to retain and strengthen affective relationships from across geographic divides. The Senegalese tirailleurs stationed in campements during World War One relied on the letters of their wives for morale (Duparc 2010). Labour migrants on the Zambian Copperbelt practised long-distance kinship and marriage long before the current era (Moore and Vaughan 1994: 150-77).

So what is new and noteworthy about African long-distance intimacy in the twenty-first century? It may be instructive to look at early critiques of the concept of transnationalism for guidance. Some scholars have been unwilling to see the phenomenon of transnationalism in migration as entirely new in content (Lewellen 2002: 11), pointing to other migrant movements that retained strong ties to their homelands. Others argued that the amplified intermingling of spaces and practices of travel, production, discipline, consumption, and accumulation' (Ong 1999: 244), as well as the expanding availability and rapid transmission of images, symbols, ideas and information, must push us to rethink our understandings of society, social institutions, citizens and nation states (Levitt

\footnotetext{
Dinah Hannaford is an assistant professor of International Studies at Texas A\&M University. She is the author of Marriage Without Borders: transnational spouses in neoliberal Senegal (University of Pennsylvania Press, 2017). Email: dhannaford1@tamu.edu
} 
and Glick Schiller 2004). These changes allowed for a new type of migrant experience and thus new ways of conceiving of the migratory project as a whole, through the notion of transnationalism.

In the early years of the study of transnationalism, many different explanations were proffered as to why the present historical moment leads to increased transnationalism among migrants. Today's technologies of transport and communication clearly allow for a far more dynamic and concentrated exchange across borders than ever before. This 'time-space compression' (see Harvey 1989) is foundational to our modern era and is a crucial component of the level of transnationalism we see today. But technological advances and time-space compression alone do not explain why immigrants today desire to spend so much of their time and resources investing in their home ties. The answer to that question, as many have argued, involves a complex mix of cultural responses to the political and economic forces of global capitalism (Basch et al. 1994: 24; Massey 1998; Sassen 1998; Levitt 2001: 25; Portes and DeWind 2007: 6).

Taking this discussion as a model, we can say that critical aspects of contemporary long-distance intimate relationships make them distinct from earlier counterparts. The time-space compression that characterizes the contemporary era is key to understanding the way in which modern transnational families represent a new way of practising kinship across distance. The instantaneity of communication and money transfer has led to what some scholars describe as 'co-presence' (Baldassar et al. 2007). Physically absent loved ones are able to retain an unprecedented degree of presence in the lives of those at home. And as with transnationalism itself, as I will argue below, the motivation to achieve co-presence comes from a mix of cultural, political and, in particular, neoliberal economic factors.

The impact of these changes is palpable to those who study transnational intimacies and often appears in unexpected ways. Although many argue that this co-presence can mean increased emotional closeness, or virtual intimacy, ethnographic research reveals that other dynamics also result. I argue that new technological opportunities for co-presence raise new expectations for financial and emotional availability between spouses. These expectations, in turn, create friction between spouses and increase the burden that migrants carry. In the case of African migrants, these expectations also leave migrants more vulnerable to the demands made on them by neoliberal sending nation states who seek to maximize the national benefits of emigration and circular migration.

\section{The disappearing phone centre}

Mariama invites me into her bedroom in the house she shares with her mother-inlaw, sister-in-law and her two children in Senegal's northern Louga region. Out in the living room, the television is blaring and Mariama's mother-in-law is shouting orders to her sister-in-law who is cooking the midday meal. Inside Mariama's bedroom is relative quiet. The bedroom has the same oversized wooden furniture (dresser and bed set) that married women often receive from their husbands when they move in with them. Although Mariama's bedroom is in the house her husband Serigne built, she does not live with him, and, aside from his short annual visit to Senegal, she never has. Serigne lives outside Milan as an economic migrant in a small apartment he shares with a cousin. 
Serigne and Mariama were just one couple I followed in my multi-sited ethnographic research project on Senegalese migration and transnational marriages. The research, which spanned seven years from 2004 to 2011, involved interviews and fieldwork in France and Italy among Senegalese migrants, as well as interviews and fieldwork in Senegal among migrants' wives. Over the course of the research, I found that many married couples opted to live separately, for reasons that spanned from financial to logistical, legal and emotional. Absent husbands and long-distance marriage have become commonplace arrangements for couples in Senegal. Although Senegalese women also migrate, transnational marriages between migrant women and non-migrant men remain quite rare for reasons that are beyond the scope of this article.

'Do you want to talk to Serigne?' Mariama asks. She opens the small laptop that Serigne had sent to her a few months earlier and signs on to Skype. Serigne is not signed on, so Mariama calls him on her Nokia mobile phone, also a gift from Serigne. They talk for a few minutes - he is out grocery shopping but will soon be home to Skype. She hands the phone to me and I chat with Serigne in Italian. I ask about his friends whom I met last time I visited him in Milan; he asks after my family and says that he hopes I'm finding hospitality in his home in Louga. He says that he insisted his sister cook me the red (tomato-based) version of Senegal's national dish, ceebu-jen, because he knows it is my favourite.

Later that day, Mariama and Serigne connect on Skype. She is lying on her stomach on the bed with the laptop when I come in to say hello. After a brief conversation - he asks if I have eaten well and how I liked his sister's ceeb - I leave them to talk among themselves. It is Serigne's day off and Mariama stays on Skype with Serigne for most of the afternoon. Her children come in and out of the room, interact with their father, and run out again. Mariama mostly lies on the bed, rising occasionally to find small change for her sons, who want to purchase snacks from a nearby shop, or to try on and show Serigne a new wig or pair of shoes she has purchased.

When I began my fieldwork in 2004, transnational Senegalese couples mostly communicated through phone calls and email. Phone centres were a mainstay in transnational marriages. In Italy and France, these phone centres were usually in migrant neighbourhoods and owned by immigrants. Senegaleseowned phone centres like the ones I frequented during my fieldwork in Turin also served as small markets, selling immigrant-oriented products such as Maggi bouillon cubes, cassava roots, African DVDs, and hair products for black hair. These centres also had transparent booths with telephones in them where immigrants could call internationally and watch meters calculate the accumulating cost of the call, a feature not possible with international calling cards and cell phones.

In the phone centre where I spent much of my time in Turin in 2004-05 and again in the summer of 2008, Senegalese migrant men would come in and out every day, sometimes to phone home, to send money via wiring services such as Western Union, or to buy various products, but often just to socialize with whomever was there and to watch the other customers come and go. These spaces had the feel of télécentres in Dakar, where neighbours would hang out for hours and chat at a leisurely pace. There were always playful arguments and teasing happening between regular clients and proprietors, while the sounds of the television or radio playing in the phone centre hummed in the background. 
Phone centres in Senegal were on every corner in 2004, and, like their European counterparts, they were hardly private spaces. The phone centre on the first floor of the house where I lived in Dakar rented DVDs, sold toiletries, and was the neighbourhood hang-out for young people, who were always planted on the centre's small bench or hanging around the doorway, chit-chatting. For a time, there was also a babyfoot (table football) table set up at the entrance where local children would gather, their cheers and squeals audible from anywhere in the house. There were two phone booths, each closed with a wooden half-door that did little to accord privacy or quiet to the user.

In both of these settings, those making long-distance calls were unable to have long, intimate phone conversations. Migrants and migrants' loved ones would often tell the phone centre clerk who was monitoring the cost of the call to tell them when the call reached a certain amount of money so that they could quickly get off the phone. If a line of people were waiting to use the phone, calls would be cut short out of courtesy to others. Making phone calls in those centres, I myself negotiated the frustration of background noise, and felt the lack of privacy every time my emotions were heightened in the course of my phone conversation.

In the early years of my research, cybercafés were the only place where most Senegalese people accessed the internet, and only a small proportion of even urban Senegalese had any use for the internet. Cybercafés were similarly public places, though that did not stop customers from eventually using social media, Skype or dating sites, playing computer games and even watching porn in them. Venables' study of women in Ziguinchor using internet dating sites to meet foreign men situates the cybercafé as a key site 'in which aspirations of migration were manifested' (2008: 472).

Over the course of my fieldwork, Wi-Fi became commonplace in private homes in Senegal (and in France and Italy). In 2016, about 3.7 million Senegalese were internet users, representing over a quarter of the population, up from an estimated 0.4 per cent in $2000 .{ }^{1}$ There is talk of a 'Dakar Digital City' project that would follow African cities such as Kigali in installing free, public Wi-Fi in large public areas around the city. More and more, in urban Senegal and in rural areas with migration connections, a home computer and internet connection are seen as necessities of modern life. At the same time, mobile phones have become ubiquitous and phone centres have all but disappeared.

Mariama, like most migrants' wives, received her first computer from her husband. He sent the small laptop through a fellow migrant who was travelling from Milan to Dakar in 2010. I helped Mariama switch the computer's operating language from Italian to French so that she could navigate it more easily. Within a week she had set up her first email account - her name followed by 2010@yahoo.fr and a Facebook account. She had already used Skype on her brother's computer when she visited Dakar, but now she downloaded Skype on to her own computer and began using it daily for hours on end - including to regularly call me and her other friends in Dakar, a few hours away.

\footnotetext{
${ }^{1}$ Figures taken from the CIA World Factbook (<https://www.cia.gov/library/publications/theworld-factbook/geos/sg.html>) and the International Telecommunication Union (ITU; < https:// www.itu.int $>$ ) respectively.
} 


\section{Co-presence and the disposability of communication}

Scholars of transnational migration are gradually probing what the emerging advances in communication technologies, or 'polymedia' (Madianou and Miller 2012: 8), can offer long-distance intimate relationships. Most agree that they 'create scapes of transconnectivity' (King-O'Riain 2015) or 'amplify emotional connection' (Panagakos and Horst 2006), and that they act as 'a transnational bridge ... to provide transnational caring to family and kin' (Plaza and Below 2014: 49). Transnational communication technologies may 'temporarily suspend emotional distress resulting from being physically separated, and may fuel the desire for reunification and resettlement' (Leurs 2014: 89).

Although letters and cassette tapes were earlier tools of providing transnational connectivity for some, newer forms of media such as texting and VoIP provide a marked change in the possibilities for maintaining near constant contact. Madianou and Miller (2011) have explored the different advantages and disadvantages Filipino migrants attributed to letters versus cassette tapes as a form of communication with those at home. Some migrants appreciated how letters were carefully crafted and took time and effort, in themselves a demonstration of love and devotion; others preferred hearing the voices of their children on cassettes as a better gauge of how they were changing, growing and feeling. Either way, both could be kept and reread or replayed, stretching out the experience of each. For both letters and cassettes, there was a long time lag between their sending and their reception, which, as Madianou and Miller suggest, 'added an emotional intensity to the exchange because of the tremendous anticipation that accompanied waiting for the next letter or cassette' (2011: 262). Letters and cassettes sent by post were an event, both in their crafting and in their reception, and in the waiting in between.

Contemporary tools of communication are quite different. Because of the compression of space and time, these tools allow for - indeed insist on - immediate and disposable communication. For most couples, mobile phone and Skype conversations are not recorded and thus disappear immediately after they are conducted. Telephone calls are certainly not events in themselves; many of my respondents spoke to their spouses every single day and some spoke multiple times a day. These quotidian conversations, many of which I witnessed on one side or the other, were generally not emotionally resonant, romantic or sentimental. They often consisted of a series of exchanged greetings and perfunctory inquiries about the health and well-being of various family members and friends. There was certainly very little emotional intensity surrounding the anticipation of phone calls, text messages or even Skype chats, and I knew both migrant husbands and non-migrant wives in transnational marriages who saw them as a burden rather than a treat.

I would argue, in fact, that the quotidian and disposable nature of these communications make them less likely to bring couples emotionally closer together than would more enduring, tangible or effortful exchanges, such as writing and posting letters or recording and sending cassettes. Partners on both sides seemed not to put much thought into what they said to one another, and the result was often that patterns of demands and disappointments characterized their interactions with little intimate emotion involved. 


\section{Perpetual availability}

I have previously written about surveillance that Senegalese migrant husbands perform on wives from afar (Hannaford 2015). Through mobile phones, landlines, webcams and so on, Senegalese migrant husbands often keep tabs on their wives' whereabouts, expecting to be informed of their comings and goings as they would have been had they remained in Senegal. Indeed, wives often maintain that their husbands are in fact much more lenient when they are not abroad. Because these technologies make spouses always reachable, inaccessibility becomes cause for suspicion of misbehaviour (see Riak Akuei 2005; Francisco 2015 for parallels in other diasporas).

Although social expectations of wives' domesticity make them more likely to be surveilled by their husbands, this expectation of availability can be a two-way street. Wives also expect their husbands to be accessible. When Mariama saw that Serigne was not signed on to Skype on his day off, she immediately tried him on his mobile phone. Some of the wives I interviewed knew their husbands' work schedules down to their lunch breaks and planned their availability for Skyping and making or receiving phone calls accordingly. Several wives whose migrant husbands' phone calls had decreased in frequency assumed that their husbands had taken on lovers or even additional wives, revealing their expectation that a faithful husband would call constantly. ${ }^{2}$

Migrant husbands complain that their accessibility creates the expectation that they will continue playing the highly gendered role of household head (borom keur) even while absent, a process that has been called 'global householding' (Kofman 2012). This expectation of global householding or global housekeeping has been explored by researchers of transnational mothering (for example, Hondagneu-Sotelo and Avila 1997; Parreñas 2005), although it is often overlooked among migrant husbands and fathers. ${ }^{3}$ Migrants in Italy spoke to me of making and receiving irritating mobile phone calls in the short breaks between their gruelling factory schedules to resolve disagreements and tensions between their mothers or sisters and their wives over issues as minor as what foods were prepared and when. They managed household budgets from overseas, furnished homes, arranged for Qur'anic tutors for children, and even occasionally did remote grocery shopping (Blanchard 2013), all from miles away. Many were involved in the minutest household decisions on a daily basis - see Serigne's long-distance dictation of what to serve me for lunch on my visit to his family home.

Although migrants sometimes complained about their efforts in this kind of global housekeeping, by and large their biggest complaints were about the constant requests for remittances they received. Like most Senegalese non-migrant wives of migrants, Mariama depends on remittances from Serigne to pay for the family's daily expenses, as well as for her own pocket money. In migrant and non-migrant homes alike, the Senegalese expectation is that a husband will

\footnotetext{
${ }^{2}$ Chort et al. (2012) use Dia (2007) to suggest that migrants are also subject to the disciplinary gaze of their entire home communities while abroad due to the profusion of mobile phone technologies.

${ }^{3}$ However, see McKay (2010) and Kilkey (2014).
} 
$y o r$, or provide for his wife and children. Although women increasingly contribute money of their own to the maintenance of the household, most Senegalese women see this as an act of helping their husband fulfil what remains his gendered duty, rather than as doing their rightful share. In households where the husband is a migrant, there is an even greater expectation that the husband will be the main provider, as he ostensibly relocated abroad with the sole intention of earning.

With the proliferation of wire-transfer businesses such as MoneyGram and Western Union, sending remittances home from abroad has never been easier or more immediate for overseas migrants. The percentage of Senegal's GDP that comes from migrant remittances has steadily and dramatically increased since the mid-2000s (Yiheyis and Woldemariam 2016: 245). Many households in Senegal depend on remittance transfers from family overseas to function on a day-to-day basis, paying for everything from rent to soap to fresh fish. So accustomed are Senegalese to receiving wire-transfer remittances from abroad that now a new and popular service called Wari (and a rapid proliferation of copycat businesses) allows for domestic wire transfers within Senegal as a means for the quotidian exchange of money within the country (Williams 2014).

Horst and Miller (2006) point out that the mobile phone makes remittance exchanges easier. Although many of my respondents received monthly transfers from their husbands, they also made requests at other times for smaller amounts, for example to buy fabric, ${ }^{4}$ pay medical bills, or help friends or relatives in need. With the ease of sending even small amounts of cash, no request is too small or too petty to be made immediately. Migrants report being called with requests to send cash to pay for things as banal as concert tickets or bus fares. This dynamic not infrequently leads to migrants feeling resentful. Although their solidarity with family and their gendered sense of duty motivate them to support their loved ones from afar, many migrants feel that the casual, constant demands suggest that their wives and family take them for granted and do not appreciate how hard they work to be able to provide remittances.

These expectations of financial availability lead to scenarios that fray the emotional bonds between spouses. Each request for remittances creates an opportunity for tension to grow. Migrants' wives I interviewed used examples of their husbands' refusals to specific requests for remittances as evidence that their husbands no longer loved them. A husband who truly loved and felt empathy for his wife would not abandon her financially, they insisted, even at the level of providing her with new fine clothing for every single ceremony or holiday. For most Senegalese women, a lack of financial availability leads to suspicions of romantic competition. Because technologies render remittance transfers so easy and immediate, many wives see a lack or a delay of remittances as a deliberate choice on the part of their migrant spouses. In Senegal, where polygamy is both legally and religiously sanctioned, a real anxiety exists among married women that husbands might be in pursuit of a second, third or fourth wife. Dwindling remittances can be seen as an indication to many wives that their husbands are directing those resources to another woman (Hannaford 2016: 98). ${ }^{5}$ Migrant husbands, as I

\footnotetext{
${ }^{4}$ See Buggenhagen (2012) on the significance of cloth in religious and social life in Senegal.

${ }^{5} \mathrm{My}$ fieldwork confirms that the fears are not unfounded. Migrant Senegalese men do put resources into the pursuit and marriage of additional wives. About one-third of the migrants'
} 
note, expressed a similar dismay at the constant requests from their wives, which they interpret as a lack of pity (yëram) and solidarity for her overtaxed husband.

June Hee Kwon explores the 'unwaged affective labour' of waiting that spouses of migrants perform while their partners are away (2015: 480). She argues that the work of waiting itself 'remakes the expectations and realities of transnational spousal relationships' (ibid.: 481). When the waiting is punctuated by continual even daily - minor disappointments, the realities and expectations of many Senegalese transnational marriages are transformed. Husbands are reframed as disappointments, and wives as nags.

This is a dynamic facilitated by new communication technologies. A longdistance couple that could not communicate easily during the period of separation, such as the Senegalese tirailleurs and their wives, might have had their romantic memories and fantasy to draw on to keep their attraction and affection for their partner alive in the interim between visits. The experience of missing and longing for one another was thus not punctuated by these continual mutual disappointments. Most Senegalese transnational couples today, however, are confronted almost daily with a particular reality of their partner - for women, perhaps the controlling and suspicious husband who monitors her every move and does not care to send enough money home; for men, this could be the remittance-hungry wife who is feuding with his mother. The potential for intimacy can as easily be obliterated by technological accessibility as facilitated.

In addition to these emotional consequences, there are important financial costs that result from the expectation of financial availability created by new technologies. Bruce Whitehouse (2013) uses Keith Hart's idea of the 'entrepreneur's social dilemma' - the conflict of managing entrepreneurial interests to accumulate privately alongside incentives to give generously in a communal society - to explain West African motivations to emigrate. By putting physical distance between themselves and their loved ones, migrants escape one of the most compelling kinds of claims on their resources - the face-to-face request - and are able to more discreetly manage their earnings and spending away from the prying eyes of claimants. Dieng (2008) also cites this desire to create distance from economically demanding kin as a key motivator for young Senegalese to migrate.

Of course, with time-space compression, this physical distance no longer represents the same kind of buffer for migrants. Instead of being shielded from the demands of loved ones while they are attempting to accumulate, Senegalese migrants are at the constant mercy of phone calls, texts, emails, Facebook messages and so on from their non-migrant loved ones. With instant wire-transfer technology now mundane, the fact that non-migrants could have the cash they desire sent instantly only increases the relentless expectation of the migrants' financial availability.

All of these expectations compound the burden placed on Senegalese migrants who are under duress to make ends meet in difficult and deteriorating conditions in Western Europe. Although migrants themselves desire and indeed participate actively in the creation of their co-presence at home for both sentimental and practical reasons (see Hannaford 2017), they also feel overwhelmed by the

wives I interviewed had co-wives, although, of course, some of those women were themselves the second, third or fourth wife. 
consequences of their accessibility. Migrants told me of their various strategies to avoid the constant requests: these include ignoring phone calls from unknown phone numbers with Senegalese area codes and shutting off their phones or staying away from social media and Skype in the frantic spending period before major holidays or family events. Many migrant husbands attempt to obscure the details of their work activities and earnings overseas in an effort to control how they remit to wives and other loved ones at home. Fully a third of migrants' wives I interviewed in 2010-11 could not name their husbands' precise job nor the exact city in which they lived; this was due in part to deliberate obfuscation on the part of migrant husbands. Because of the technological potential for accessibility, however, even when they can avoid being reachable, migrants cannot dodge the expectations of availability.

\section{The expectations of neoliberal states}

As noted above, the motivation to retain and strengthen transnational intimate connections comes not only from sentiment, but from a mix of the cultural, political and economic realities that shape the lives of migrants and their kin. For the postcolonial African state, expectations of the financial and emotional availability of migrants play an important role in absolving the state of many of its responsibilities to its citizens. Migrants are increasingly responsible not only to their families, but to their entire communities and to the state.

The advance of neoliberal globalization and the adoption of economic reforms in much of sub-Saharan Africa have led to significant cutbacks in the public provision of social services, including in healthcare and education. Across subSaharan Africa, these cutbacks have hit African citizens across class categories, not only the rural poor (MacLean 2011). The fallout of structural adjustment programmes in Senegal has led to the slashing of social services, the shrinking of civilsector employment, and extreme inflation. Access to healthcare and education has become more and more tenuous in Senegal as a result. Market-based reforms in healthcare, combined with a crumbling economy, have created tremendous hurdles for citizens and healthcare providers alike (Foley 2010). Inequalities in access to education persist between rural and urban Senegalese (Diene 2014), and disappointing salary structures and a lack of teacher training result in declining performance in schools and a higher drop-out rate (DeStefano et al. 2009).

In my interviews with migrants and their wives, both parties frequently alluded to requests for remittances for prescription medicine, ultrasounds and doctors' visits of various kinds. Similarly, my interviewees also discussed the payment of school fees as a key duty that they felt towards their families, for the migrants' own children as well as the children of relatives. This includes helping families access Qur'anic education and paying for private schools, uniforms and other school supplies. Indeed, some migrants suggested that, because paying for medical bills and school fees seemed like an unequivocal obligation of a migrant, they suspected that some requests for medical expenses or school fees were in fact a cover for purchasing other things that they might otherwise have said no to (Tazanu 2018).

Providing for parents always ranks first among the motivations my migrant interlocutors cite for their migration. Senegal has an extremely low level of 
pension, and, due to financial problems in both the private and public pension institutions, the Senegal Pension Insurance Institution (IPRES) and the National Pension (FNR), pensioners cannot be assured of receiving their pensions (DeVreyer and Roubaud 2013: 377-80). The pensions that exist are rarely enough to run a household, so even retirees with pensions generally rely on their children and other relatives for maintenance.

Maguette, an interviewee in her late forties, is one migrant's wife whose family has been impacted by the pension problem in Senegal. Her husband had worked as a police officer for his entire adult life, but could never afford to buy or build a home while also supporting his family's needs. When he retired at fifty-seven, his pension was 40,000 CFA (about US\$80) every two months, a sum that could not begin to cover his rent or family expenses. 'Imagine that you work until retirement and you have no home, no nothing,' Maguette told me as we discussed her family's dilemma. 'You fatigue your wife, you fatigue your children.' Maguette's husband felt that he had no choice but to leave his wife and four school-aged children at home and migrate to Portugal.

Maguette and her children did not support this decision. 'This travel makes no sense because he's old and he can't do anything,' she complained. Indeed, because of his age and his undocumented status, Maguette's husband's migration has failed to produce results and his family is still struggling at home. Maguette makes and sells breakfast items in her lower-class neighbourhood of Dakar to provide some income for her family, but is often too sick and tired to work. She has type 2 diabetes and cannot afford her prescribed medication. She expects that soon her eldest son will migrate to Portugal when he completes his studies so that he can begin supporting her and his siblings and so that her husband can return home. When he goes, supplementing his father's meagre pension and covering his mother's medical expenses will become his responsibility.

The financial availability of migrants is presumed not just by families, but by the nation state as well. The trend in migration literature is to highlight and laud the potential of migrant remittances for development. In Senegal, overseas migrants, both individually and in regional or religious associations, have come to fill the vacuum of services left by the government. Senegalese migrant associations have been active in providing healthcare services to those abandoned by neoliberal reforms (Kane 2010), as well as participating in infrastructure and development projects at home, from building wells to building hospitals (Foley and Babou 2011).

Serigne is a member of a regional association of migrants from his part of Senegal. This association has contributed funds to and organized the implementation of development projects in his home town, including building a new mosque, improving a school building, and helping with irrigation for agriculture. The new mosque had a large banner on it announcing the migrant association as the benefactors and Serigne and his fellow members felt tremendous pride in having brought it to completion.

Many of my migrant interlocutors participated in these kinds of associations, giving not just their funds but also their energy and their time to improving infrastructure in their home communities. Serigne participated in this process while also building a home to house his mother and other members of his family, paying for their medical expenses and covering the school fees of his children, his nieces and nephews and his cousins. The retrenchment of the social welfare 
state means that the burdens of being a 'provider' as a husband, a father or a son have swelled to include provisions that were once the responsibility of the state.

The Senegalese economy - like many African nations with large emigrant populations - benefits enormously from what Brenda Chalfin calls 'an economics of exodus' (2010: 201). Remittances from overseas migrants constitute a significant percentage of the country's GDP and the state is working towards directing those remittances to long-term development projects. The World Bank says that African migrants remit twice as much as the average migrant from other developing countries. During the past twenty years, remittance flows into Africa have quadrupled, reaching US\$40 billion in 2010. In 2010, overseas migrants sent an estimated US\$1.4 billion in remittances to Senegal - about 10 per cent of the country's GDP. Senegalese remittances dwarf the numbers in neighbouring countries, according to a study carried out by the Central Bank of West African States (BCEAO).

Senegal has a 'Ministry of Senegalese Abroad' (Ministère des Sénégalais de l'Extérieur) whose central mission is to retain the participation of the Senegalese diaspora in civic and economic life in Senegal. Although the ministry promotes itself as providing rights to Senegalese citizens overseas, in true neoliberal fashion it explicitly lays out a newer vision of citizenship that emphasizes duties over rights. The Ministry of Senegalese Abroad routinely interpolates Senegalese migrants as 'the real actors of development' whose concerns hold a 'prominent place' in the eyes of the state. ${ }^{6}$ The ministry pursues a more effective state usage of the remittances flowing into Senegal by convincing migrants of the important role they play in national development projects. Political efforts have concentrated on convincing Senegalese abroad to make productive investments in the country (see Diatta and Mbow 1999).

In January 2017, in fact, lawmakers in Senegal accorded a record number of parliamentary seats to the Senegalese diaspora. Almost 10 per cent of seats in parliament would now be for Senegalese citizens living abroad, indicating a clear understanding of the diaspora as a significant engine of economic development for the country. MP Amadou Bâ noted that the diaspora was the 'principal financial backer of Senegal', and thus deserved even more seats. ${ }^{7}$

The Ministry of Senegalese Abroad expresses ambivalence about how migrants currently use their remittances: namely, how much of those remittances are funnelled to what they call 'consumption needs' for the household (MSE 2011: 29, cited in Sinatti 2015: 90) rather than into economic schemes that would benefit the development of the country as a whole. In 2013, while she held the office of Minister of Senegalese Abroad, Seynabou Gaye Touré lamented in an interview with a main national Senegalese newspaper that one of her office's chief ambitions was to change the fact that most of the remittances Senegalese migrants send home are consumed by families or used for home construction (Dione 2013).

\footnotetext{
${ }^{6}$ 'L'État accorde une place prépondérante aux préoccupations de ses citoyens expatriés', '[d]es véritables acteurs de développement', according to then Minister of Senegalese Abroad, Seynabou Gaye Touré (see Dione 2013).

7 750 milliards/an: "La diaspora, principal bailleur du Sénégal", Seneweb, 15 March 2017 $<$ http://www.seneweb.com/news/Economie/950-milliards-an-laquo-la-diaspora-princ_n_210764. html>.
} 
Consumption needs account for an estimated 90 per cent of Senegalese migrants' remittances according to the government (Republic of Senegal 2012: 10, cited in Sinatti 2015: 91).

This critique must be examined in the context of a neoliberal economic environment in which healthcare and education have become commodities, and civil service jobs and their pensions have dwindled. The government of Senegal's own privatization and retrenchment reforms, albeit carried out under duress from international lending organizations, have created an environment in which many Senegalese households must rely heavily on migrant dollars for their dayto-day functioning. This investment of remittances into household consumption is not an ignorant or frivolous choice, as the state's critique suggests, but a matter of survival.

In the same interview, MP Touré asserted that her ministry had plans to alter the way in which migrants invest their remittances. 'Today, we are working to reorient this important financial mass towards investment in key growth areas, in a way that doesn't keep them from maintaining an active solidarity with their families back home' (Dione 2013). The Senegalese government encourages migrants to make investment in their country's development a priority, while at the same time underlining their responsibility to support their families financially - through 'active solidarity' - while abroad. The rhetoric of the migrant as dutiful son and dutiful citizen that is underlined here by the state puts the onus on migrants instead of the state for social welfare and development, as remittances are meant to 'trickle up' (Rodriguez 2010: xvii) and pay for the state. If the government's picture of migrant life is the worker and family man who dutifully sends money home from abroad to invest in social projects such as supporting the family but is also responsible for investing in the country's development, the migrant thus becomes doubly responsible for duties that once fell to the state before neoliberal reforms.

This narrative has profound effects on individual Senegalese migrants themselves, many of whom already struggle to stay afloat financially while meeting overwhelming demands for remittances from friends and family back home. My migrant interlocutors claim that non-migrant families and friends see those migrants who do not get rich as personal failures who must not have worked hard enough to secure the riches that apparently can be found abroad. This narrative fits neatly into the neoliberal idea of self-reliance and personal accountability, expecting individuals to overcome all structural barriers through sheer willpower and determination.

Senegal is far from alone in its strategy to harness migrant remittances for state use. Other African nations such as Ghana have also tried (with mixed success) to direct migrant remittances towards development projects (Kleist 2015). ${ }^{8}$ As Rodriguez notes of the Philippines, this strategy is 'quintessentially neoliberal', as the state 'withdraws social supports and thereby passes on the costs of education, health care, and other expenses to its citizens' (2010: xix). For nations in Africa struggling under debt to find a pathway to prosperity or social stability,

\footnotetext{
${ }^{8}$ Even when African migrants return from abroad, they are still burdened with these expectations that they will dedicate themselves to the development of their homeland (see Åkesson and Eriksson Baaz 2015).
} 
labour brokering appears to be an effective way of exploiting the developed world's need for cheap labour, often at the expense of citizens' family lives.

\section{Conclusion}

The vast majority of my Senegalese migrant interlocutors tell me that if economic and social constraints had not compelled them to migrate, they would prefer to be living in Senegal and prefer not to be participating in transnational intimate relationships. Although the romantic possibilities of virtual intimacy are compelling, we must follow the reminder of Francisco (2015), who warns us not to be seduced by the connective potential of technology. If we do so, we risk ignoring that its use is 'the result of an induced geography for families who would otherwise not choose to be apart' (ibid.: 189).

Further, I would argue that we cannot allow connective potential to blind us to disconnective realities. As I have shown, both the immediacy of communication technologies and the instantaneity of electronic money transfers create new demands on Senegalese transnational couples. New expectations for immediacy and accessibility arise with a new global technoscape (Appadurai 1996), and, with them, new parameters for what it means to be generous, attentive and dutiful. ${ }^{9}$ Among the transnational couples I interviewed, these expectations often led to tensions and a sense of disconnection. The ease, immediacy and disposability of communication rendered their communication less romantic, more mundane, and prone to disenchantment and disappointment.

As I have shown, the state joins in and benefits from familial expectations about migrants' duties towards their families. The narrative that a dutiful son supports his parents through migration and remittances takes the pressure off the state to provide a robust social security or pension programme. The narrative that a good father is one who leaves his wife and children behind and travels overseas to put food on the table and pay medical bills absolves the state of the responsibility to invest in job creation programmes or affordable state healthcare.

Furthermore, the state also creates expectations about the financial availability of the migrant vis-à-vis the state itself. Explicitly in state policy and rhetoric, migrants are positioned as 'providers' for the state. The idea that responsible village dwellers will move abroad to collectively provide community members with the infrastructure and social services they need also takes those responsibilities away from the state. Championing the economic power and heroism of migrants as citizens coheres with neoliberal African states' objectives in profiting from the labour of their overseas citizens.

Transnational parenting, transnational elder care and transnational marriage are becoming ordinary ways of performing kin roles in the twenty-first century. More and more, familial bonds are being stretched across great distances, and,

\footnotetext{
${ }^{9}$ This expectation manifests in ways that differ across different types of relationships. In this article, I have looked specifically at the impact of new technologies on marital dynamics. Other authors (such as Vives and Vazquez Silva 2016; Parreñas 2005; Schmalzbauer 2004; 2015; Lan 2006; Wilding 2006) have explored the impact of technology on other kinds of transnational intimate relationship - that of mother and child, for example.
} 
for many African citizens, this distance and separation are part of what it means to have intimate relationships in the contemporary era (see Cole and Groes 2016). Newer technologies that allow for regular and immediate connectivity can create expectations for the accessibility of migrants that in turn leave them more vulnerable to demands of family, communities and the state through narratives of duty and honour that insist on a solidarity-minded claim to the migrants' resources. The unprecedented possibility of 'co-presence' in twenty-first-century migration has profoundly ambivalent consequences for African migrants both as citizens and as spouses.

\section{References}

Adepoju, A. (1979) 'Migration and socio-economic change in Africa', International Social Science Journal XXXI (2): 207-25.

Åkesson, L. and M. Eriksson Baaz (eds) (2015) Africa's Return Migrations: the new developers? London: Zed Books.

Appadurai, A. (1996) Modernity at Large: cultural dimensions of globalization. Minneapolis MN: Minnesota University Press.

Baldassar, L., C. Baldock and R. Wilding (2007) Families Caring Across Borders: migration, ageing and transnational caregiving. Basingstoke: Palgrave Macmillan.

Basch, L., N. Glick Schiller and C. Szanton Blanc (1994) Nations Unbound: transnational projects, postcolonial predicaments, and deterritorialized nation-states. New York NY: Routledge.

Blanchard, M. (2013) 'Rethinking family relations through the allocation of emigration's resources: Senegalese migrants' use of e-commerce', Migration Letters 10 (1): 47-55.

Buggenhagen, B. (2012) Muslim Families in Global Senegal: money takes care of shame. Bloomington IN: Indiana University Press.

Chalfin, B. (2010) Neoliberal Frontiers: an ethnography of sovereignty in West Africa. Chicago IL: University of Chicago Press.

Chort, I., F. Gubert and J.-N. Senne (2012) 'Migrant networks as a basis for social control: remittance incentives among Senegalese in France and Italy', Regional Science and Urban Economics 42: 858-74.

Cole, J. and C. Groes (2016) Affective Circuits: African migrations to Europe and the pursuit of social regeneration. Chicago IL: University of Chicago Press.

Declich, F. and M. Rodet (2018) 'Introduction: (re)thinking migration memories and diasporic practices from the perspective of the African continent', Africa 88 (3): 443-51.

DeStefano, J., M. R. Lynd and B. Thornton (2009) The Quality of Basic Education in Senegal: a review. Boston MA: Center for Collaboration and the Future of Schooling.

DeVreyer, P. and F. Roubaud (2013) Urban Labor Markets in Sub-Saharan Africa. Washington DC: World Bank.

Dia, H. (2007) 'Le portable dans la vallée du fleuve Sénégal', Ágora 46: 70-80.

Diatta, M. A. and N. Mbow (1999) 'Releasing the development potential of return migration: the case of Senegal', International Migration 37 (1): 243-66.

Diene, M. (2014) 'Inequalities in the context of structural transformation: the case of Senegal', Development 77 (3-4): 540-6. 
Dieng, S. A. (2008) 'Déterminants, caractéristiques et enjeux de la migration sénégalaise' in E. Bouilly and N. Marx (eds), 'Migrations et Sénégal: pratiques, discours et politiques', Revue Asylon $(s)$ no. 3.

Dione, B. (2013) 'Seynabou Gaye Touré, ministre des Sénégalais de l'extérieur: "En trois ans, l'État a reçu 810 projets provenant des émigrés"', Le Soleil, 12 July $<$ http://www.seneweb.com/news/Developpement/seynabou-gaye-toure-ministre-dessenegalais-de-1-exterieur-laquo-en-trois-ans-1-rsquo-etat-a-recu-810-projets-provenantdes_n_100264.html>, accessed 6 August 2018.

Duparc, C. (2010) 'Les femmes des tirailleurs sénégalais de 1857 à nous jours', Genre \& Histoire 6.

Feldman-Savelsberg, P. (2016) Mothers on the Move: reproducing belonging between Africa and Europe. Chicago IL: University of Chicago Press.

Flahaux, M.-L. and H. De Haas (2016) 'African migration: trends, patterns, drivers', Comparative Migration Studies 4 (1): 1.

Foley, E. (2010) Your Pocket is What Cures You: the politics of health in Senegal. New Brunswick NJ: Rutgers University Press.

Foley, E. and C. A. Babou (2011) 'Diaspora, faith, and science: building a Mouride hospital in Senegal', African Affairs 110 (438): 75-95.

Francisco, V. (2015) "The internet is magic": technology, intimacy and transnational families', Critical Sociology 41 (1): 173-90.

Hannaford, D. (2015) 'Technologies of the spouse: intimate surveillance in Senegalese transnational marriages', Global Networks 15 (1): 43-59.

Hannaford, D. (2016) 'Intimate remittances: marriage, migration, and MoneyGram in Senegal', Africa Today 62 (3): 93-109.

Hannaford, D. (2017) Marriage Without Borders: transnational spouses in neoliberal Senegal. Philadelphia PA: University of Pennsylvania Press.

Harvey, D. (1989) The Condition of Postmodernity: an enquiry into the origins of cultural change. Oxford: Blackwell.

Hondagneu-Sotelo, P. and E. Avila (1997) “"I'm here, but I'm there”: the meanings of Latina transnational motherhood', Gender and Society 11: 548-71.

Horst, H. and D. Miller (2006) The Cell Phone: an anthropology of communication. Oxford: Berg.

Kane, A. (2010) 'Charity and self-help: migrants' social networks and health care in the homeland', Anthropology Today 26 (4): 8-12.

Kane, A. and T. H. Leedy (2013) African Migrations: partners and perspectives. Indianapolis IN: Indiana University Press.

Kilkey, M. (2014) 'Polish male migrants in London: the circulation of fatherly care' in L. Baldassar and L. Merla (eds), Transnational Families, Migration and the Circulation of Care. New York NY: Routledge.

King-O'Riain, R. C. (2015) 'Emotional streaming and transconnectivity: Skype and emotion practices in transnational families in Ireland', Global Networks 15 (2): 256-73.

Kleist, N. (2015) 'Policy spectacles: promoting migration-development scenarios in Ghana' in D. Vigneswaran and J. Quirk (eds), Mobility Makes States: migration and power in Africa. Philadelphia PA: University of Pennsylvania Press.

Kofman, E. (2012) 'Rethinking care through social reproduction: articulating circuits of migration', Social Politics 19 (1): 142-62.

Kwon, J. H. (2015) 'The work of waiting: love and money in Korean Chinese transnational migration', Cultural Anthropology 30 (3): 477-500. 
Lan, P. C. (2006) Global Cinderellas: migrant domestics and newly rich employers in Taiwan. Durham NC: Duke University Press.

Leurs, K. (2014) 'The politics of transnational affective capital: digital connectivity among young Somalis stranded in Ethiopia', Crossings: Journal of Migration and Culture 4 (1): 87-104.

Levitt, P. (2001) The Transnational Villagers. Berkeley CA: University of California Press.

Levitt, P. and N. Glick Schiller (2004) 'Conceptualizing simultaneity: a transnational social field perspective on society', International Migration Review 38 (3): 1002-39.

Lewellen, T. C. (2002) The Anthropology of Globalization: cultural anthropology enters the 21st century. Westport CT: Bergin \& Garvey.

MacLean, L. M. (2011) 'The paradox of state retrenchment in sub-Saharan Africa: the micro-level experience of public social service provision', World Development 39 (7): 1155-65.

Madianou, M. and D. Miller (2011) 'Crafting love: letters and cassette tapes in transnational Filipino family communication', South East Asia Research 19 (2): 249-72.

Madianou, M. and D. Miller (2012) Migration and New Media: transnational families and polymedia. New York NY: Routledge.

Massey, D. S. (1998) Worlds in Motion: understanding international migration at the end of the millennium. Oxford and New York NY: Clarendon Press.

McKay, S. (2010) "'So they remember me when I'm gone": remittances, fatherhood and gender relations of Filipino migrant men' in L. Hoang and B. Yeoh (eds), Transnational Labour Migration: remittances and the changing family in Asia. Singapore: Asia Research Institute, National University of Singapore.

Moore, H. L. and M. A. Vaughan (1994) Cutting Down Trees: gender, nutrition and change in the Northern Province of Zambia, 1890-1990. Portsmouth NH: Heinemann.

MSE (2011) 'Lettre de politique sectorielle des Sénégalais de l'Extérieur'. Dakar: Ministère des Sénégalais de l'Extérieur (MSE), Direction des Sénégalais de l'Extérieur.

Ong, A. (1999) Flexible Citizenship: the cultural logics of transnationality. Durham NC: Duke University Press.

Panagakos, A. N. and H. A. Horst (2006) 'Return to cyberia: technology and the social worlds of transnational migrants', Global Networks 6 (2): 109-24.

Parreñas, R. S. (2005) 'Long-distance intimacy: class, gender and intergenerational relations between mothers and children in Filipino transnational families', Global Networks 5 (4): 317-36.

Plaza, D. and A. Below (2014) 'Social media as a tool for transnational caregiving for the Caribbean diaspora', Social and Economic Studies 63 (1): 25-56.

Portes, A. and J. DeWind (2007) Rethinking Migration: new theoretical and empirical perspectives. New York NY: Berghahn Books.

Republic of Senegal (2012) SNDES 2013-2017: stratégie nationale de développement economique et social: sur la rampe de l'émergence. Dakar: Republic of Senegal.

Riak Akuei, S. (2005) 'Remittances as unforeseen burdens: the livelihoods and social obligations of Sudanese refugees', Global Migration Perspectives 18: 1-16. 
Rodriguez, R. (2010) Migrants for Export: how the Philippine state brokers labor for the world. Minneapolis MN: University of Minnesota Press.

Sassen, S. (1998) Globalization and its Discontents: essays on the new mobility of people and money. New York NY: The New Press.

Schmalzbauer, L. (2004) 'Searching for wages and mothering from afar: the case of Honduran transnational families', Journal of Marriage and Family 66 (5): 1317-31.

Schmalzbauer, L. (2015) 'Temporary and transnational: gender and emotion in the lives of Mexican guestworker fathers', Ethnic and Racial Studies 38: 211-26.

Sinatti, G. (2015) "“Come back, invest, and advance the country”: policy myths and migrant realities of return and development in Senegal' in L. Åkesson and M. Eriksson Baaz (eds), Africa's Return Migrations: the new developers? London: Zed Books.

Tazanu, P. (2018) 'Communication technologies and legitimate consumption: making sense of healthcare remittances in Cameroonian transnational relationships', Africa 88 (2): 385-403.

Trémon, A.-C. (2017) 'Flexible kinship: shaping transnational families among the Chinese in Tahiti', Journal of the Royal Anthropological Institute 23 (1): 42-60.

Venables, E. (2008) 'Senegalese women and the cyber café: online dating and aspirations of transnational migration in Ziguinchor', African and Asian Studies 7 (4): 471-90.

Vives, L. and I. Vazquez Silva (2016) 'Senegalese migration to Spain: transnational mothering practices', Journal of Ethnic and Migration Studies 43 (3): 495-512.

Whitehouse, B. (2012) Migrants and Strangers in an African City: exile, dignity, belonging. Bloomington IN: Indiana University Press.

Whitehouse, B. (2013) 'Overcoming the economistic fallacy: social determinants of voluntary migration from the Sahel to the Congo Basin' in A. Kane and T. H. Leedy (eds), African Migrations: partners and perspectives. Indianapolis IN: Indiana University Press.

Wilding, R. (2006) "Virtual” intimacies? Families communicating across transnational contexts', Global Networks 6 (2): 125-42.

Williams, S. (2014) 'Wari: boosting financial inclusion', New African 50-1.

Yiheyis, Z. and K. Woldemariam (2016) 'The effect of remittances on domestic capital formation in select African countries: a comparative empirical analysis', Journal of International Development 28: 243-65.

\begin{abstract}
This article examines how African transnational relationships in the twenty-first century differ from their manifestation in previous periods of mobility and long-distance intimacy. I argue that the possibilities for and expectations of immediate communication and co-presence facilitated by the current technological landscape distinguish this era from earlier ones and fundamentally alter the ways in which African migrants connect to those at home. Although time-space compression allows for the potential of new practices of virtual intimacy, it also creates an imperative of availability for migrants that is reinforced not only on
\end{abstract}


micro- and meso-levels by families and communities but also on macro-levels by neoliberal state policies that target migrants as agents of development and providers of social services.

\section{Résumé}

Cet article examine en quoi les relations transnationales africaines au vingt-etunième siècle diffèrent dans leurs manifestations des périodes précédentes de mobilité et d'intimité à longue distance. L'auteur soutient que les possibilités et les attentes de communication immédiate, ainsi que la coprésence facilitée par le paysage technologique actuel, différencient cette ère des précédentes et modifient fondamentalement les modes de connexion entre les migrants africains et les non-migrants restés au pays. La compression de l'espace-temps permet la possibilité de nouvelles pratiques d'intimité virtuelle, mais elle crée également pour les migrants un impératif de disponibilité renforcé non seulement aux niveaux micro et méso par les familles et les communautés, mais également au niveau macro par les politiques d'État néolibérales visant les migrants en tant qu'agents de développement et fournisseurs de services sociaux. 